\title{
Editorial: 30 Years Journal of Population Economics
}

\author{
Klaus F. Zimmermann ${ }^{1,2}$
}

Published online: 8 October 2016

(C) Springer-Verlag Berlin Heidelberg 2016

Issue 1/2017 marks an important landmark for the Journal of Population Economics. The Journal enters its 30th year of successful academic service. We celebrate three decades of dedication in publishing outstanding theoretical and insightful applied research in all areas of population economics. Nobel Laureates, renowned scientists in the field, established researchers and junior up-and-coming researchers have been contributing to the Journal. In 1987, when the first articles were evaluated for the inaugural issue that came out in 1988, population economics was a rather peripheral field in economics without a dedicated platform for studying, discussing, and publishing such research. However, there was a rising interest in the area inspired by the path breaking contributions of Jakob Mincer, Gary Becker, Richard Easterlin, Marc Nerlove and Robert Fogel, among others.

These leading and influential scientists were all working at US universities. Europeans were still trying to catch up in this area, let alone having the Journal dedicated to population economics. The demographic associations based in Europe at the time were not interested in absorbing the contributions by economists, in particular because demographers and sociologists were still apprehensive of the "imperialism" of economists and their rigorous mathematical treatment of the subject. So some of us took the initiative in Europe to create a new and much needed scientific association, the European Society for Population Economics in 1986. The Journal of Population Economics became the independent partner of the Society. It was not accidental that I took, at the time, the role of the Secretary of the Society as well as the Managing Editor of the Journal. Germany and its researchers with the foreseeable long-term demographic challenges was a natural core of the European-based initiative.

Soon after the Journal took off, high international demand made it de facto global. It became a decisive instrument to establish and promote the field of population economics in all parts of the world. While, nowadays, there is a mushrooming number of

Klaus F. Zimmermann

klaus.f.zimmermann@gmail.com

1 UNU-MERIT, Maastricht, The Netherlands

2 Harvard University, Cambridge, MA, USA 
competing journals dealing with issues of economic demography, the international and independent Journal of Population Economics has strongly established itself as the leading outlet in the field of population economics. By the 1990s, the field has risen to prominence, with Gary Becker (1992) and Robert Fogel (1993) receiving the Nobel Prize in Economics for their seminal work in areas of population economics. Throughout the decades, the Journal of Population Economics has been at the forefront of population economics research. The quotes below by leading scientists from economics, history, sociology, political science and demography witness this.

Since the beginning, the Journal of Population Economics has been published in cooperation with the Society and with Springer-Verlag as the publisher. Over the decades, the Journal was also supported by the institutions I was affiliated with including the University of Pennsylvania, the University of Mannheim, the Seminar for Labor and Population Economics of Munich University, the Institute for the Study of Labor, the Center for European Studies at Harvard University and the Industrial Relations Section of Princeton University. Since 2016, the Journal is hosted by POP Centre for Population, Development and Labor Economics at the United Nations University - Maastricht Economic and Social Research Institute on Innovation and Technology (UNU-MERIT).

The Journal of Population Economics owes its success to the devoted engagement of the many Editors, Associate Editors, Managing Editors and Editorial Assistants. We are grateful to the unknown heroes, the referees, for the thousands of referee reports they have written to critically and constructively evaluate the submissions. And we are proud of the ever rising number of excellent authors who submit their best work and entrust us to judge their high caliber research. The research community keeps a loyal relationship to the articles in the Journal. And last but not least, we thank the host institutions and Springer-Verlag for all the support we have received over the 30 years. We are looking forward to further success stories.

Klaus F. Zimmermann, Editor-in-Chief, Journal of Population Economics

\section{Some views on the Journal of Population Economics.}

\section{"I read each issue"}

I congratulate the Journal of Population Economics on the advent of its 30th year of publication. Its founder and chief editor-Klaus Zimmermann - and his editorial boards - have done an outstanding job in creating a high quality forum for research on the economics of the household, migration, fertility, education and health. I read each issue with interest and have learned much from it over the years. I wish it continued success.

\section{James J. Heckman, Henry Schultz Distinguished Service Professor of Econom- ics at the University of Chicago, Nobel Prize Winner in Economics}

\section{"will become more important than ever"}

The core of every economy is its population and a dedicated journal was long overdue when the Journal of Population Economics was launched. With our stagnant populations, ageing and immigration the topics on which it focuses will become more 
important than ever. As it turns 30 it promises to occupy an ever-important place in the profession and we should all be thankful for its existence.

Sir Christopher Pissarides, Regius Professor of Economics at the London School of Economics, Nobel Prize Winner in Economics

\section{"one of the most important journals of economics"}

The Journal of Population Economics straddles an important space between demography and formal economics that, while always important, had been neglected before the journal came into existence. In the thirty years since its inception the journal has seen a most remarkable climb to prominence. It witnessed a steady rise in impact factor over the last decade and has established itself as one of the most important journals of economics.

Kaushik Basu, Chief Economist and Senior Vice President at the World Bank, Professor of Economics and C. Marks Professor at Cornell University.

\section{"a must read"}

The Journal of Population Economics had become the go to place for research at the intersection of economics and demography. In a world where issues such as aging populations and migration demand policy responses, the journal has become a must read.

\section{Janet Currie, Henry Putnam Professor of Economics and Public Affairs and Director of the Center for Health and Well-Being at Princeton University}

\section{"look forward to the next 30 years"}

In the last 30 years, the Journal of Population Economics has published influential research in many salient realms of economic life worldwide, from migration problems to gender issues, from intergenerational matters to public policies, and from inequality and poverty to health, education and economic growth.

In a world characterized by increasing political and economic uncertainty, greater flows of people around the globe, climate change and an explosion of data availability, the Journal is likely to continue to attract and publish high quality research from the expanding army of applied social scientists in all areas of population economics.

We all look forward to the next 30 years of publications in the Journal of Population Economics!

Marco Francesconi, Professor of Economics at the University of Essex, UK, and ESPE President 2017

\section{"an exceptional flagship for population economics"}

In somewhat typical style 29 years ago, Klaus Zimmermann, Editor-in-Chief, expressed the following ambitions for Population Economics - the new journal should cover all aspects of the fascinating, new and promising field. The journal should be international with a high reputation. The first issue should be perfectly balanced-it was not, of course, insufficient empirical work for his taste! But the promises have been 
truly kept. The latest issue includes empirical articles based on data from America, France, Netherlands, China, Africa, Sweden and Canada. The journal is an exceptional flagship for population economics.

Bob Gregory, Emeritus Professor of the Research School of Economics at the Australian National University

\section{"great insights for scholars and policymakers"}

The areas covered by the Journal of Population Economics, everything from demographic change to migration and human capital, are vital issues for national and international development in the 21st century. For thirty years the Journal of Population Economics has published cutting-edge research in the field providing great insights for scholars and policymakers alike. Happy birthday Journal of Population Economics and congratulations to Klaus Zimmermann and the entire editorial team!

James F. Hollifield, Professor of International Political Economy and Director of the Tower Center for Political Studies at the Southern Methodist University, USA

"a global forum for the rigorous exchange on scientific ideas"

It is a pleasure to congratulate the Journal of Population Economics - and its editors, authors, and reviewers - on the journal's 30th anniversary. With every passing year, the Journal of Population Economics becomes more fully a global forum for the rigorous exchange of scientific ideas on population dynamics, stretching from a core of economic principles to join sibling disciplines in producing new theoretical and empirical knowledge.

Guillermina Jasso, Silver Professor and Professor of Sociology at New York University, USA

\section{"Its reputation and success have surged"}

The Journal of Population Economics has long provided a great home for articles on population economics, and a forum for discussion of the many important scientific and policy issues involving demography. Its reputation and success have surged. Happy 30th Birthday, J Popul Econ!

Ronald Lee, Edward G. and Nancy S. Jordan Family Professor Emeritus of Economics, Professor Emeritus of Demography and Associate Director, Center for the Economics and Demography of Aging (CEDA) at University of California, Berkeley, USA

\section{"leading journal of economic demography"}

The Journal of Population Economics has established itself as the leading journal of economic demography, covering a range of related topics in migration/immigration, development, and the economics of the family. If fills an important niche between the standard labor economics journals and the interdisciplinary demography journals. 
David Neumark, Chancellor's Professor of Economics and Director, Economic Self-Sufficiency Policy Research Institute (ESSPRI) at the University of California, Irvine, USA

\section{"took a vacant position among economics journals"}

The Journal of Population Economics took a vacant position among economics journals when it started in 1987 as a high quality journal in areas like migration, family economics, human capital and education. These fields have become extremely important for economic growth and development today, 30 years later. Congratulations to the farsighted and successful founders of Journal of Population Economics and especially the pioneer Klaus Zimmermann. Best wishes for the next 30 years of great volumes from JOPE!

\section{Nina Smith, Professor of Economics at Aarhus University}

"leading outlet for academic research on economic and demographic problems" Congratulations for the 30th anniversary of the Journal of Population Economics! It has been a leading outlet for academic research on economic and demographic problems for the past 30 years and I am sure it will continue to be so.

Xiangquan Zeng, Professor of Economics and Director of the China Institute for Employment Research (CIER) at Renmin University of China 